\title{
EFEKTIVITAS DETEKSI DINI GANGGUAN BAHASA DAN BICARA DI POSYANDU ANYELIR DAN POSYANDU SEKAR ASIH KOTA BANDUNG
}

\author{
Yosrika \\ Prodi Diploma Tiga Terapi Wicara Politeknik Al Islam Bandung \\ Email: rikabandung@yahoo.com
}

\begin{abstract}
ABSTRAK
Pertumbuhan dan perkembangan anak balita sangat penting untuk dipantau, mengingat periode tersebut merupakan periode emas (Golden Age) di masa tumbuh kembang anak. Pada periode tersebut keterlambatan atau gangguan pada tumbuh kembang anak sangat mungkin terjadi. Salah satu gangguan perkembangan yang sering dijumpai adalah keterlambatan bicara. Deteksi dini gangguan bahasa dan bicara akan sangat membantu para orang tua untuk menggambarkan apakah anaknya mengalami keterlambatan berbicara atau ada gangguan lainnya. Namun demikian, banyak orang tua tidak memiliki pengetahuan yang cukup mengenai gangguan bahasa dan bicara ini. Berdasarkan kondisi tersebut, penelitian ini bertujuan untuk mengetahui efektifitas deteksi dini gangguan bahasa dan bicara di Posyandu Anyelir dan Sekar Asih untuk menumbuhkan kesadaran mengenai pentingnya deteksi dini bagi balita. Penelitian ini menggunakan pendekatan kualitatif dengan pengumpulan data melalui teknik wawancara, observasi, dan studi dokumentasi. Hasil dari penelitian menunjukkan bahwa tingkat kesadaran orang tua meningkat terhadap pertumbuhan dan perkembangan bahasa anaknya setelah para orang tua mendapatkan informasi mengenai deteksi dini gangguan bahasa dan bicara. Dengan deteksi dini mengenai masalah yang dialami oleh anaknya, maka orang tua dapat mendapatkan informasi dan penanganan lebih lanjut jika diperlukan.
\end{abstract}

Kata kunci: efektivitas, deteksi dini, gangguan bahasa, gangguan bicara, posyandu

\begin{abstract}
The growth and development of children under five very important to be monitored, considering that this period is the golden age period during the child's development. Some children experience developmental delays or disorders. One of the developmental disorders that are often encountered is a speech delay. Early detection of language and speech disorders will greatly help parents to describe whether their children have speech delays or other disorders. However, many parents do not have sufficient knowledge about language and speech disorders. Based on this condition, this study aims to determine the effectiveness of early detection of language and speech disorders at Anyelir Posyandu and Sekar Asih Posyandu to raise awareness about the importance of early detection for toddlers. This study used a qualitative approach with data collection through the technique of interview, observation, and documentation study. Results of the study showed that the level of awareness among parents increases on the growth and development of their children's language after parents got information about early detection of language and speech disorders. By
\end{abstract}


doing early detection on the problems experinced by their children, parents can get further information and treatment if needed.

Keywords: early detection, effectiveness, language disorder, speech disorder, posyandu

\section{PENDAHULUAN}

Setiap orang tua menginginkan anaknya tumbuh dan berkembang normal, tetapi tidak semua pertumbuhan dan perkembangan anak sesuai dengan harapan orang tua. Menurut Soetjiningsih (1994) pertumbuhan dan perkembangan anak dipengaruhi oleh faktor genetik dan faktor lingkungan. Faktor genetik merupakan modal dasar dalam mencapai hasil akhir proses tumbuh kembang anak, sedangkan faktor lingkungan sangat menentukan tercapai atau tidaknya potensi bawaan. Lingkungan yang cukup baik akan memungkinkan tercapainya potensi bawaan, sedangkan yang kurang baik akan menghambatnya. Tanuwijaya (2003) dalam artikel Nur Chamidah (2009) mengatakan bahwa secara garis besar faktor lingkungan terbagi menjadi faktor lingkungan yang mempengaruhi anak pada waktu bayi masih dalam kandungan (faktor pranatal) dan faktor lingkungan yang mempengaruhi tumbuh kembang anak setelah lahir (faktor postnatal).

Perkembangan terjadi secara teratur mengikuti pola atau arah tertentu. Perkembangan pada lima tahun pertama kehidupan anak sangat penting (Butchon, 2017). Setiap tahap perkembangan merupakan hasil perkembangan dari tahap sebelumnya yang merupakan prasyarat bagi perkembangan selanjutnya. Sebagai contoh, untuk dapat berbicara anak harus melewati tahaptahap perkembangan bahasa bicara seperti vokalisasi, babbling, laling, ekolali sebagai prasyarat bagi perkembangan selanjutnya Hal ini sesuai dengan Berry MF dalam (Soetjiningsih, 2015) yang mengemukakan bahwa perkembangan bicara dan bahasa anak normal dapat dibagi melalui 5 fase yaitu Reflex vocalization (usia 0-1,5 bulan), Cooing (usia 2-4 bulan), Babbling (usia 1,5-6 bulan), Lalling (usia 6 bulan), Echolalia (usia 9-10 bulan), dan True Speech (usia 12-13 bulan).

Dari studi di lapangan, banyak tenaga medis di puskesmas tidak melakukan deteksi pertumbuhan dan perkembangan anak dengan detail karena keterbatasan waktu dan orang tua yang belum memahami proses pertumbuhan dan perkembangan anak sering kali menganggap biasa jika anak mengalami masalah dan gangguan dalam bicara. Keterlambatan berbicara dan gangguan berbicara adalah dua hal yang berbeda, keterlambatan berbicara biasanya hanya disebabkan oleh kurangmya stimulasi dari lingkungan, tetapi gangguan berbicara biasanya disebabkan oleh banyak faktor seperti gangguan anatomis dan neurologis

Program Deteksi Dini Tumbuh Kembang Anak sangat diperlukan untuk memantau tumbuh kembang anak dan hal ini sesuai dengan pendapat dari Alisjahbana (2010) yang menyatakan bahwa deteksi dini sangat diperlukan untuk bisa memantau pertumbuhan dan perkembangan anak untuk menemukan adanya indikasi penyimpangan pertumbuhan dan perkembangan. Deteksi dini kelainan

pertumbuhan dan perkembangan anak akan sangat berguna, agar diagnosis maupun pemulihannya dapat dilakukan lebih awal, sehingga pertumbuhan dan perkembangan anak dapat berlangsung seoptimal mungkin (Dardjito, 2014). Bila terdapat penyimpangan pertumbuhan di usia dini, maka tindakan koreksi akan memberikan hasil yang memuaskan, sedangkan bila penyimpangan terjadi pada usia dini tetapi baru dideteksi pada usia yang lebih lanjut, hasil koreksi akan kurang memuaskan. Deteksi dini bisa dilakukan mulai dari keluarga, Posyandu, puskesmas, klinik tumbuh kembang anak, sampai rumah sakit. Penilaian tumbuh kembang anak dapat dilakukan dengan berdasarkan pada Pedoman Deteksi Dini Tumbuh Balita yang dikeluarkan oleh Tim Dirjen Pembinaan Kesmas (Narendra (2003) dalam nur Chamidah (2009)). 
Kader dan orang tua sebagai orang yang terdekat dengan anak sangat perlu untuk mendapatkan pembelajaran mengenai pertumbuhan dan perkembangan anak. Proses pembelajaran ini dapat diberikan oleh tenaga kesehatan yang memahami pertumbuhan dan perkembangan anak. Proses pembelajaran ini memerlukan manajemen perencanaan dan pelaksanaan yang baik agar materi yang diberikan bisa dipahami oleh orang tua dan tenaga kader. Dengan memiliki pengetahuan mengenai cara melakukan Deteksi Dini Tumbuh Kembang Anak melalui proses pembelajaran yang baik, maka orang tua bisa melakukan pemeriksaan deteksi dini tumbuh kembang anak untuk anaknya sendiri dan untuk orang lain jika diperlukan. Hal ini dapat juga meningkatkan rasa percaya diri orang tua karena mereka bisa memiliki pengetahuan bermanfaat bagi orang lain.

Seperti dikemukakan di awal, proses pertumbuhan dan perkembangan anak sangat penting untuk diperhatikan oleh banyak pihak. Proses ini juga merupakan proses yang saling berkesinambungan. Keberadaan Posyandu sebagai salah satu pusat kegiatan kesehatan dasar yang diselenggarakan dari, oleh, dan untuk masyarakat yang dibantu oleh petugas kesehatan sangat bermanfaat untuk lingkungan sekitar (Encang, 2017). Salah satu kegiatan Posyandu adalah untuk memberikan pelayanan kesehatan kepada balita seperti imunisasi, penimbangan berat badan, pengukuran tinggi badan, pemberian makanan tambahan, dan lain-lain. Informasi mengenai deteksi dini gangguan berbahasa dan berbicara untuk orang tua dan kader di puskesmas juga sangat diperlukan agar orang tua dan kader bisa mengetahui sejak dini keterlambatan atau gangguan bahasa dan bicara pada anak. Dengan kunjungan rutin ke Posyandu, indikasi penyimpangan perkembangan dan pertumbuhan akan lebih cepat terdeteksi. Semakin dini permasalahan diketahui, semakin cepat juga penanganan yang diberikan. Peneliti berharap melalui dibuatnya penelitian ini dapat meningkatkan pengetahuan orang tua dan kader mengenai deteksi dini gangguan bahasa dan bicara.

\section{METODOLOGI PENELITIAN}

\section{Pendekatan dan Metode Penelitian}

Penelitian ini menggunakan pendekatan penelitian kualitatif, dengan lebih menekankan pada aspek pemahaman secara mendalam, terhadap suatu masalah dan menggunakan teknik analisis mendalam, dengan mendeskripsikan dan menganalisa data secara menyeluruh tentang masalah yang diteliti. Jenis penelitian yang digunakan adalah penelitian deskriptif dengan menggambarkan atau memaparkan data yang diperoleh peneliti berkaitan dengan pembahasan Manajemen Pembelajaran Deteksi Dini Tumbuh Kembang Anak Usia Balita dalam Optimalisasi Kesehatan Anak di Posyandu Anyelir RW 11, Kelurahan Sukamaju, Kecamatan Cibenying Kidul, Kota Bandung dan Posyandu Sekar Asih RW 04, Kelurahan Jamika, Kecamatan Bojongloa Kaler, Kota Bandung.

\section{Teknik dan Instrumen Pengumpulan Data}

Teknik pengumpulan data dalam penelitian ini menggunakan teknik wawancara, observasi dan studi dokumentasi. Dalam hal ini peneliti mengadakan wawancara dengan responden secara langsung untuk mendapatkan data-data atau informasi yang diperlukan tentang permasalahan yang berkaitan dengan manajemen pembelajaran deteksi dini tumbuh kembang anak usia balita dalam optimalisasi kesehatan anak. Teknik observasi juga digunakan dalam penelitian ini untuk mendukung perolehan data dari hasil wawancara. Peneliti secara langsung melakukan pengamatan terhadap objek penelitian guna memperoleh berbagai informasi yang dibutuhkan sesuai dengan fokus penelitian. Selain itu, studi dokumentasi juga dilakukan untuk mendukung data-data yang telah diperoleh dari hasil wawancara dan observasi. Teknik studi dokumentasi ini dilakukan dengan cara mempelajari dokumen-dokumen yang berhubungan dengan objek yang diteliti baik berupa arsip, buku-buku, kartu kunjungan dan lain-lain. Dokumen-dokumen itu berguna untuk lebih 
memperjelas dan dapat memberikan latar belakang yang lebih luas mengenai pokok permasalahan yang diteliti. Penelitian ini dilakukan pada bulan Mei 2017 sampai dengan bulan Juli 2017 dengan tahapan sebagai berikut:

Tabel 1. Tabel Kegiatan Penelitian

\begin{tabular}{ll}
\hline \multicolumn{1}{c}{ Bulan } & \multicolumn{1}{c}{ Kegiatan } \\
\hline Mei 2017 & $\begin{array}{l}\text { Observasi di Posyandu Anyelir dan Posyandu } \\
\text { Sekar Asih }\end{array}$ \\
\hline Juni 2017 & $\begin{array}{l}\text { Penyuluhan Deteksi Gangguan Bahasa dan } \\
\text { Bicara }\end{array}$ \\
\hline Juli 2017 & $\begin{array}{l}\text { Aplikasi Deteksi Dini di Posyandu Anyelir dan } \\
\text { Sekar Asih }\end{array}$ \\
&
\end{tabular}

\section{Lokasi dan Subjek Penelitian}

Penelitian ini dilaksanakan di dua Posyandu, Posyandu Anyelir RW 11, Kelurahan Sukamaju, Kecamatan Cibeunying Kidul, Kota Bandung dan Posyandu Sekar Asih RW 04, Kelurahan Jamika, Kecamatan Bojongloa Kaler, Kota Bandung. Kedua posyandu tersebut menjadi sampel penelitian dari populasi Posyandu di Kota Bandung. Sampel dalam penelitian kualitatif diambil tidak secara acak, akan tetapi bersifat purposive atau sampel bertujuan.

Subjek dalam penelitian ini adalah kader dan orang tua yang berkaitan langsung dalam Manajemen Pembelajaran Deteksi Dini usia balita. Penelitian ini menggunakan pendekatan kualitatif, oleh karena itu subjek penelitian atau sumber data sebagai informan diperoleh dari Kader dan orang tua. Subjek penelitian tersebut dianggap akan memberikan informasi tentang masalah yang akan diteliti, disesuaikan dengan tujuan penelitian melalui teknik wawancara, observasi, dan studi dokumentasi.

\section{HASIL DAN PEMBAHASAN}

\section{Deteksi Dini Tumbuh Kembang Balita}

Penyuluhan deteksi dini gangguan bahasa dan bicara dilaksanakan sebagai bagian dari penelitian ini. Dalam penyuluhan disampaikan informasi mengenai deteksi dini tumbuh kembang anak dalam bentuk poster yang dibuat oleh Yayasan Surya Kanti Bandung. Poster ini bisa dijadikan sebagai panduan bagi orang tua untuk memantau pertumbuhan dan perkembangan anaknya terutama untuk masalah bahasa dan bicaranya.

\section{Temuan Penelitian di Posyandu Anyelir}

Posyandu Anyelir RW 11 adalah satu dari 12 Posyandu di wilayah Kelurahan Sukamaju, Kecamatan Cibeunying Kidul, Kota Bandung. Posyandu ini berada di bawah binaan Puskesmas Padasuka. Petugas kesehatan yang ditunjuk sebagai pembina Posyandu ini adalah Ibu Bidan Fahmi dan koordinatorya adalah Bapak Rizal. Posyandu Anyelir menyelenggarakan berbagai kegiatan pendukung diantaranya adalah program penyuluhan kesehatan. Salah satu program yang dilaksanakan di Posyandu adalah pelatihan mengenai deteksi dini gangguan bahasa dan bicara pada anak yang dilaksanakan bersama dengan peneliti. Kegiatan ini banyak diminati oleh para warga, hal ini terbukti dari banyaknya kunjungan para ibu saat dilakukan pelatihan dan demonstrasi pada anak batita di sana. 


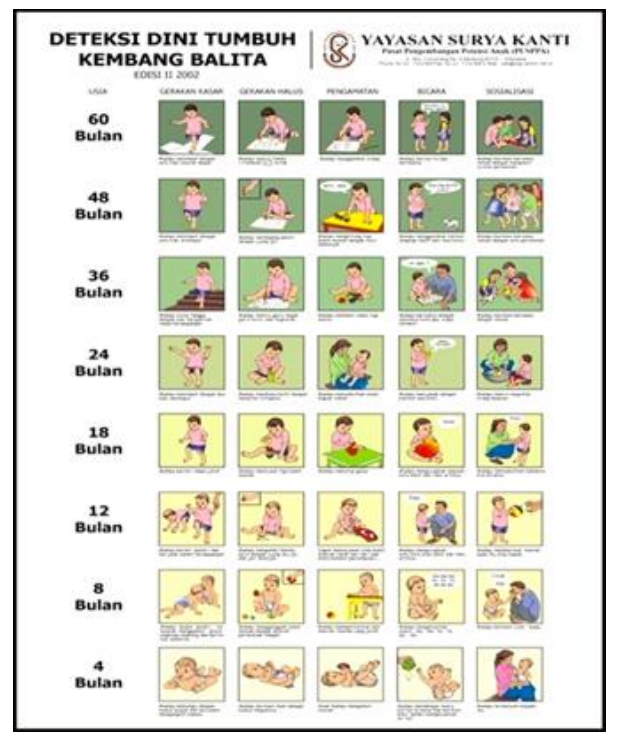

Gambar 1. Poster Deteksi Dini Tumbuh Kembang Anak

Dari observasi yang dilakukan pada bulan Mei 2017 di Posyandu Anyelir, ditemukan bahwa dalam melaksanakan tugasnya para kader di Posyandu ini lebih banyak melakukan pemeriksaan pada aspek pertumbuhan saja, seperti menimbang berat badan, mengukur lingkar kepala dan tinggi badan. Padahal, perkembangan anak seharusnya juga mempertimbangkan beberapa aspek lain diantaranya adalah gerakan motorik kasar, motorik halus, pengamatan, bicara, dan sosialisasi. Setelah para kader mendapat pengetahuan mengenai deteksi dini gangguan bahasa dan bicara, para kader dan orang tua dapat mendeteksi dini gangguan bahasa dan bicara. Sebelumnya banyak orang tua yang masih beranggapan bahwa anak yang sehat adalah anak yang gemuk, padahal hal tersebut tidak menjamin bahwa perkembangan anak baik. Banyak ibu yang juga masih beranggapan bahwa anak yang mengalami keterlambatan bicara adalah hal yang wajar, padahal jika dibiarkan mungkin akan berdampak panjang dalam kehidupan anak tersebut. Pelatihan deteksi dini gangguan bahasa dan bicara yang dilakukan cukup berhasil. Hal ini terlihat dari antusias para ibu yang banyak bertanya mengenai informasi deteksi dini gangguan bahasa dan bicara yang disampaikan lewat poster yang dibuat oleh Yayasan Surya Kanti Bandung. Para orang tua juga saat ini dapat melakukan deteksi dini pada anak mereka.

Temuan lainnya berkaitan dengan aplikasi dari pelatihan itu sendiri. Dari data yang para kader peroleh pada bulan Juni 2017, dari 30 batita, 10 batita tidak memiliki indikasi keterlambatan bicara, 17 orang mengalami keterlambatan berbicara, dan 3 orang memiliki indikasi gangguan bahasa dan berbicara. Dengan mengetahui data ini maka dapat disimpulkan bahwa indikasi keterlambatan bebicara di Posyandu ini cukup tinggi. Kader dapat memberikan saran untuk pemeriksaan lanjutan pada puskesmas atau klinik tumbuh kembang anak.

Hal lain yang juga menjadi perhatian adalah sarana dan prasarana untuk pembelajaran deteksi dini yang kurang mendukung dan pada akhirnya berpengaruh pada perencanaan program. Posyandu ini belum memiliki tempat yang tetap sehingga alat-alat yang dibutuhkan sering kali dibawa dari satu tempat ke tempat yang lain. Peranan kader di Posyandu ini juga sangat penting karena dengan kader yang memiliki motivasi belajar yang tinggi dan terbuka dengan perubahan dapat membantu proses pembelajaran deteksi gangguan bahasa bicara menjadi lebih mudah dipahami. Para ibu juga dapat dengan mudah melakukan deteksi dini terhadap anak mereka masing-masing karena mereka tidak perlu melakukan pemeriksaan dalam waktu yang lama. Mereka cukup melihat gambar dalam poster dan mengikuti apa yang mereka pelajari dari poster tersebut. Melalui kegiatan ini orang tua menjadi lebih sadar akan pentingnya deteksi dini pada perkembangan bahasa dan bicara anak. 


\section{Temuan Penelitian di Posyandu Sekar Asih}

Posyandu Sekar Asih RW 04 merupakan salah satu Posyandu dari 16 Posyandu yang berlokasi di Kelurahan Jamika, Kecamatan Bojongloa Kaler Bandung. Posyandu ini dikenal juga dengan nama Posyandu Toleransi Sekar Asih. Ridwan Kamil yang pada saat itu menjabat walikota meresmikan Posyandu ini menjadi Posyandu toleransi pada tanggal 20 Agustus 2017. Posyandu Sekar Asih mempunyai berbagai kegiatan pendukung untuk kader-kadernya, berupa penyuluhan yang diberikan oleh petugas kesehatan. Namun, para kader baru mendapatkan penyuluhan mengenai deteksi dini gangguan bahasa dan bicara dari peneliti. Oleh karena itu, para kader sangat antusias dengan adanya program ini.

Dari hasil temuan di lapangan, pengaplikasian program deteksi dini gangguan bahasa dan bicara yang dilakukan pada bulan Juli 2017 sudah terkoordinasi dengan cukup baik di Posyandu Sekar Asih. Terlihat ada kerjasama yang baik antara ketua kader, anggota kader dan para ibu di lingkungan RW 04 kelurahan Jamika. Para kader di posyandu ini kompak dan mempunyai komitmen yang kuat dalam melakukan pekerjaannya, termasuk melakukan deteksi dini gangguan bahasa dan bicara pada anak di lingkungan tersebut. Dari hasil observasi yang dilakukan pada posyandu ini sebelum mendapatkan pengetahuan mengenai deteksi dini gangguan bahasa dan bicara, para kader hanya melakuan pemeriksaan pertumbuhan saja yang meliputi penimbangan berat badan dan pengukuran tinggi badan dan lingkar kepala. Setelah mendapatkan pemahaman mengenai deteksi dini gangguan bicara dan bahasa, para kader dan orang tua mulai terbuka pandangannya bahwa deteksi dini mengenai gangguan bahasa dan bicara sangat penting karena jika tidak ditangani dengan tepat akan berdampak panjang pada kehidupan anak.

Temuan lainnya yang didapatkan dari penelitian ini adalah jumlah kunjungan pada bulan Juli 2017 yang mencapai 105 kunjungan dengan 17 kunjungan bayi dan 88 kunjungan batita. Bagi peneliti, jumlah ini merupakan jumlah yang banyak karena jumlah kunjungan ini hanya berasal dari kunjungan satu RW. Di posyandu ini tidak semua orang tua berminat untuk melakukan deteksi dini gangguan bahasa dan bicara karena merasa tidak ada masalah berbahasa dan berbicara dengan anaknya. Dari 20 batita yang bersedia melakukan deteksi dini, didapatkan 5 batita yang mengalami keterlambatan bahasa. Data ini menunjukkan bahwa deteksi dini dapat membantu memantau perkembangan bahasa dan bicara anak.

Meskipun koordinasi program deteksi dini gangguan bahasa dan bicara di Posyandu Sekar Asih sudah cukup baik, namun pada dasarnya belum berjalan dan dilaksanakan dengan optimal. Dalam pelaksanaannya masih ditemukan banyak kendala. Hal ini terjadi karena beberapa alasan diantaranya karena usia para kader yang sudah lanjut sehingga berpengaruh pada motivasi serta waktu yang lama untuk bisa memahami materi. Selain itu, beberapa ibu masih ada yang beranggapan bahwa deteksi dini di Posyandu tidak penting, karena yang melakukan bukan petugas kesehatan, sehingga banyak dari mereka enggan datang ke posyandu. Beberapa kader juga merasa kesulitan untuk melakukan deteksi dini secara formal karena mereka belum terbiasa sehingga memerlukan waktu yang agak lama.

\section{KESIMPULAN}

Keterlambatan berbicara perlu ditangani sedini mungkin karena keterlambatan berbicara ini dapat berdampak panjang bagi anak, diantaranya anak dapat mengalami kesulitan belajar karena ada masalah di pemahaman bahasanya. Karenanya, pengetahuan deteksi dini gangguan bahasa dan bicara sangat diperlukan bagi kader dan orang tua, sehingga saat orang tua mengetahui anaknya memiliki indikasi keterlambatan berbicara sebaiknya orang tua segera berkonsultasi dengan kader dan puskesmas setempat. Sosialisasi deteksi dini gangguan bahasa dan bicara dalam bentuk poster sederhana juga sangat diperlukan oleh para kader dan orang tua untuk dapat memberikan gambaran 
kepada orang tua tentang perkembangan bicara anaknya. Semakin dini masalah diketahui semakin cepat juga diberikan stimuasi dan intervensi bagi anak, sehingga diharapkan perkembangan bicaranya menjadi optimal. Hasil penelitian menunjukkan bahwa setelah dilakukan sosialisasi deteksi dini, respon kader dan orang tua terlihat cukup besar. Hal ini terlihat dari bertambahnya pemeriksaan untuk menilai perkembangan balita di posyandu (yang biasanya hanya memeriksa penilaian pertumbuhan balita saja), banyaknya partisipan yang bertanya pada saat sosialisasi berlangsung dan juga dari jumlah kunjungan para orang tua yang memiliki balita yang meningkat, serta keterlibatan para partisipan dengan memeriksakan para balitanya dalam kegiatan deteksi dini, di mana pada pelaksanaan deteksi dini tersebut ditemukan 17 kasus balita mengalami keterlambatan berbicara, dan 8 orang memiliki indikasi gangguan bahasa. Dengan adanya temuantemuan tersebut, maka dapat disimpulkan bahwa pelaksanaan kegiatan deteksi dini efektif dalam menyampaikan informasi dan menilai gangguan bicara dan bahasa di masyarakat. Untuk penelitian selanjutnya disarankan sosialisasi deteksi dini dilakukan dengan metode yang berbeda untuk mendapatkan variasi dalam menyampaikan informasi tersebut.

\section{UCAPAN TERIMA KASIH}

Peneliti mengucapkan terima kasih yang sebesar-besarnya kepada keluarga yang senantiasa menemani, Politeknik Al Islam Bandung yang sudah mendanai penelitian ini melalui program Penelitian Dosen Pemula, dan terimakasih juga kepada Yayasan Surya Kanti Bandung serta semua pihak atas dukungan dan partisipasinya dalam penelitian ini.

\section{DAFTAR PUSTAKA}

Abdurahman, A. (2009). Cara Mengatasi Perkembangan Anak. Jakarta: Buku Kita.

Alisjahbana, Anna (2000). Deteksi Dini Tumbuh Kembang Anak. Bandung: Yayasan Surya Kanti.

Arifin, Daeng. (2010). Manajemen Pembelajaran Efektif. Bandung: Pustaka Al Kasyf.

Butchon, Rukmanee.et.al. (2017). The Development and Growth of Children Aged under 5 years in Northeastern Thailand: a Cross-Sectional Study. Journal of Child and Adolescent Behaviour 05(01) DOI: 10.4172/2375-4494.1000334

Dardjito, Endo dkk. (2014). Deteksi Pertumbuhan dan Perkembangan Balita Melalui Penggunaan Buku KIA. Kesmasindo, Volume 6, ( 3) Januari 2014, Hal. 166-175

Fikawan, S., dkk .(2016). Gizi Ibu dan Bayi. Jakarta: Raja Grafindo Persada.

Kartono, K. (2007). Perkembangan Anak. Bandung: Mandar Maju.

Moleong, Lexy. (2014). Metode Penelitian Kualitatif. Bandung: Remaja Rosdakarya.

Nur Chamidah, Atien. (2009). Deteksi Dini Gangguan Pertumbuhan dan Perkembangan Anak. Jurnal Pendidikan Khusus Vol 5 No.2 November 2009

Saepudin, Encang. (2017). Peran Posyandu Sebagai Pusat Informasi Kesehatan Ibu dan Anak. Record and Library Journal. Volume 3, Nomor 2, Juli 2017

Soetjiningsih. (1994). Tumbuh Kembang Anak. Jakarta: Penerbit Buku Kedokteran, EGC.

Sugandi, Ahmad. (2004). Teori Pembelajaran. Semarang: UPT MKK, UNNES.

Sulaksana, Henky. (2018, Desember 15). Begini Caranya Menjadikan Posyandu Multifungsional. Online (tersedia): http/www.mujabar.com

Sukmadinata, S., dkk. (2017). Panduan Penulisan Karya Tulis Ilmiah Makalah, Laporan Buku, Tesis, dan Disertasi. Bandung: Unversitas Islam Nusantara.

Sunarsih, T. (2018). Promosi Kesehatan Untuk Pengembangan Anak Usia Dini. Yogjakarta: PT Pustaka Pelajar. 